\title{
ALTITUDE TRAINING AND PHYSIOLOGICAL CONDITIONING FROM THE PRACTICAL POINT OF VIEW OF THE RUNNER
}

\author{
T. F. K. JOHNSTON and D. M. TURNER, PhD \\ International Athletes Club
}

An individual's adaptation to altitude and the likely improvement in sea level performance resulting from it are not easily predicted from a knowledge of his sea-level performances. In Mellerowicz's study (Table 1) the outstanding sea-level runner (Oh) had the largest decrement on first going to altitude but showed the greatest improvement during the four weeks at St Moritz. The slowest sea-level runner (Ec) on the other hand was least affected by altitude initially but showed the smallest improvement on return to sea level. Indeed, his sea-level time on first returning from St Moritz was slower than his time immediately before his departure to altitude. This table illustrates the astonishing individual variation both in response to altitude and in the benefit gained on return to sea level. Even at the end of four weeks the original "pecking order" has not been restored and seven of 11 individuals are still improving - and two continuing to get worse steadily.
From Mellerowicz's investigations it appears that the decrement on first going to altitude averages $5.6 \%$ for moderately fit athletes running $3,000 \mathrm{~m}$ who are paying their first visit to altitude. This compares with a decrement of $8.5 \%$ for international athletes running 3 miles $(4,800 \mathrm{~m})$, and $6.1 \%$ for a similar group running the same distance in Font Romeu at a slightly lower altitude. Mellerowicz's policemen made a much greater improvement at altitude than was achieved by the international athletes in the latter studies (Tables II and III) - a $4.4 \%$ improvement, corresponding to $29 \mathrm{sec}$ over $3,000 \mathrm{~m}$, as opposed to the $2.8 \%$ and $2 \%$ improvements corresponding to $17 \mathrm{sec}$, over $4,800 \mathrm{~m}$ of the international athletes.

On their return to sea level Mellerowicz's athletes showed an immediate net gain from their visit to St Moritz of approximately $1.5-2 \%$ over the control

\begin{tabular}{|c|c|c|c|c|}
\hline \multicolumn{5}{|c|}{$\begin{array}{l}\text { TABLE I } \\
\text { Analysis of times taken to run } 3,000 \mathrm{~m} \\
\text { at sea level and in St Moritz }(2,500 \mathrm{~m})\end{array}$} \\
\hline Runner & $\begin{array}{l}\text { Decrement } \\
\text { on first going } \\
\text { to altitude } \\
\text { (sec) }\end{array}$ & $\begin{array}{l}\text { Improvement } \\
\text { after four weeks } \\
\text { at altitude } \\
\text { (sec) }\end{array}$ & $\begin{array}{l}\text { Improvement } \\
\text { on first return } \\
\text { at sea-level } \\
\text { (sec) }\end{array}$ & $\begin{array}{l}\text { Net gain from } \\
\text { visit to altitude - } \\
\text { adjusted } \\
\text { (sec) }\end{array}$ \\
\hline $\begin{array}{l}\mathrm{Ma} \\
\mathrm{Bo} \\
\mathrm{Ev} \\
\mathrm{He} \\
\mathrm{Oh}^{*} \\
\mathrm{Si} \\
\mathrm{Pf} \\
\mathrm{Ni} \\
\mathrm{Ei} \\
\mathrm{Ec} \\
\mathrm{Bo}\end{array}$ & $\begin{array}{l}52 \\
23 \\
31 \\
30 \\
71 \\
45 \\
27 \\
30 \\
25 \\
22 \\
29\end{array}$ & $\begin{array}{l}48 \\
16 \\
23 \\
38 \\
55 \\
37 \\
27 \\
34 \\
32 \\
27 \\
-20\end{array}$ & $\begin{array}{r}32 \\
28 \\
26 \\
35 \\
40 \\
25 \\
23 \\
31 \\
22 \\
8 \\
58\end{array}$ & $\begin{array}{r}13 \\
6 \\
7 \\
28 \\
9 \\
2 \\
8 \\
20 \\
14 \\
-2 \\
-6\end{array}$ \\
\hline $\begin{array}{l}\text { Average } \\
\text { change }\end{array}$ & $\begin{array}{l}35 \\
(5.6 \%)\end{array}$ & $\begin{array}{l}29 \\
(4.4 \%)\end{array}$ & $\begin{array}{l}30 \\
(4.7 \%)\end{array}$ & $\begin{array}{c}9 \\
(1.5 \%)\end{array}$ \\
\hline
\end{tabular}

(After Mellerowicz et al, 1970)

\footnotetext{
* fastest sea-level runner

oslowest sea-level runner
} 
TABLE \|

Analysis of times taken to run 3 miles at sea level and in Mexico City (2,250m), 1965

\begin{tabular}{|l|l|l|}
\hline & $\begin{array}{l}\text { Decrement on } \\
\text { first going to } \\
\text { altitude } \\
\text { (sec) }\end{array}$ & $\begin{array}{l}\text { Improvement } \\
\text { during four } \\
\text { weeks at } \\
\text { altitude } \\
\text { (sec) }\end{array}$ \\
\hline JC & 59 & 9 \\
DK & 49 & 13 \\
MH & 56 & NA \\
Geoff N & 78 & 34 \\
Gerry N & 72 & 24 \\
DMT & 58 & 24 \\
Average & 62 & 17 \\
change & $(8.5 \%)$ & $(2.8 \%)$ \\
\hline
\end{tabular}

(After Pugh, 1967)

\begin{tabular}{|c|c|c|}
\hline \multicolumn{3}{|c|}{$\begin{array}{l}\text { TABLE III } \\
\text { Analysis of times taken to run } 3 \text { miles } \\
\text { at sea level and in Font Romeu }(1,800 \mathrm{~m}), 1967\end{array}$} \\
\hline Runner & $\begin{array}{l}\text { Decrement on } \\
\text { first going to } \\
\text { altitude } \\
\text { (sec) }\end{array}$ & $\begin{array}{l}\text { Improvement } \\
\text { during } 17 \text { days } \\
\text { at altitude } \\
\text { (sec) }\end{array}$ \\
\hline $\begin{array}{l}\text { DJH } \\
\text { REH } \\
\text { TFKJ } \\
\text { JT } \\
\text { DMT }\end{array}$ & $\begin{array}{l}33 \\
61 \\
\text { NA } \\
41 \\
63\end{array}$ & $\begin{array}{l}-2 \\
16 \\
14 \\
27 \\
13\end{array}$ \\
\hline $\begin{array}{l}\text { Average } \\
\text { change }\end{array}$ & $\begin{array}{l}50 \\
(6.1 \%)\end{array}$ & $\begin{array}{l}17 \\
(2 \%)\end{array}$ \\
\hline
\end{tabular}

(Johnston and Turner, 1967)

group who remained at sea level. There is, presumably, a connection between the improvement achieved at altitude and the net gain likely to be achieved on returning to sea level. We hazard that for fit athletes this net gain $(1.5-2 \%$ in Mellerowicz's study of moderately fit policemen) will be no greater than $1 \%$ for international athletes after their first visits to altitude. (i.e. $50 \mathrm{~m}$ in $5000 \mathrm{~m}$ or $100 \mathrm{~m}$ in $10,000 \mathrm{~m}$ ).
The beneficial effects of altitude training on racing performance are, however, likely to increase with successive visits to altitude. Table IV indicates how DMT's performances at altitude improved over a three-year period during which he made three visits to Mexico City and one to Font Romeu. Table $V$ shows his increasing adaptation to altitude stress in terms of the amount of training he was able to absorb at altitude. By his fourth visit his training routine was practically identical with that which he was maintaining at sea level. DMT's morning pulse rate (that is, within one minute of waking) was recorded in his diary as follows: in 1965 during the first seven days in Mexico City it was 43, 45, $50,44,48,45,44-$ in that week he ran only 45 miles. This contrasts with the week in 1968 when he ran 102 miles in Mexico City, when his heart rate was 40, 40, 42, 42, 41, 40, 40.

The effect of altitude when the athlete returns to sea level has not been analysed satisfactorily. However, DMT's training diary records the details of what happened to him in 1965 he unfortunately did not come back until December 5, and had no races before Christmas, so the figures were not particularly significant.

In 1967 he had two visits to altitude, and this was when he started to notice a considerable difference. He came back from Mexico City on November 2 - in fact, he had a run at Richmond Park on that day - and November 4 competed in a cross-country race against South London, Portsmouth, and Walton, in which a large number of internationals were running, and won easily. On November 7 he had two cross-country races, and won both. On November 11 and 25 he had two more cross-country races, which he won.

In 1968 he flew in from Mexico City at 9.30 a.m. on November 1, went back to Cambridge, took the train for London on November 2, and ran a cross-country race in very wet conditions at Roehampton, recording the second fastest time ever on the old $7 \frac{1}{2}$ mile course. On November 5 he won two races again and on the ninth he broke Tulloh's course record in a road race.

The subjective impression he gained was that there are advantages in going to altitude only if the athlete is able to make successive visits. It seems nonsense to talk about periods of $5,10,14$, or 20 days. When an athlete is used to coming down from altitude to compete at sea level, it is possible for him to do so within $\mathbf{2 4}$ hours, and certainly with in $1 \%$ of his best.

Middle-distance runners are creatures of habit and, if not well advised, will continue to follow their normal sea-level training routine at altitude which, for track athletes, includes a high proportion of anaerobic interval training sessions. As the British athletes found in 1965, 


\begin{tabular}{|c|c|c|c|}
\hline \multicolumn{4}{|c|}{$\begin{array}{c}\text { TABLE IV } \\
\text { Training diary of an international athlete (DMT) } \\
\text { at sea level and altitude, } 1965-68\end{array}$} \\
\hline Elevation & Date & Distance & Time \\
\hline Sea level & $\begin{array}{l}1965 \\
17 \text { Oct } \\
24 \text { Oct }\end{array}$ & $\begin{array}{l}3 \text { miles } \\
3 \text { miles }\end{array}$ & $\begin{array}{l}\text { 13: } 45.6 \\
\text { 13: } 56.8 \\
\text { (heavy cold) }\end{array}$ \\
\hline $\begin{array}{l}\text { Mexico City } \\
(2,250 \mathrm{~m})\end{array}$ & $\begin{array}{r}10 \text { Nov } \\
18 \text { Nov } \\
26 \text { Nov } \\
5 \text { Dec }\end{array}$ & $\begin{array}{l}3 \text { miles } \\
3 \text { miles } \\
3 \text { miles } \\
3 \text { miles }\end{array}$ & $\begin{array}{l}\text { 14: } 54.4 \\
14: 48 \\
14: 35 \\
14: 30.2\end{array}$ \\
\hline Sea level & $\begin{array}{l}1967 \\
13 \text { Sept }\end{array}$ & 3 miles & $\begin{array}{l}\text { 13: } 23.6 \\
\text { (personal best) }\end{array}$ \\
\hline $\begin{array}{l}\text { Font Romeu } \\
(1,800 \mathrm{~m})\end{array}$ & $\begin{array}{l}22 \text { Sept } \\
28 \text { Sept } \\
5 \text { Oct }\end{array}$ & $\begin{array}{l}3 \text { miles } \\
3 \text { miles } \\
3 \text { miles }\end{array}$ & $\begin{array}{l}\text { 14: } 26 \\
14: 21.4 \\
14: 13\end{array}$ \\
\hline $\begin{array}{l}\text { Mexico City } \\
(2,250 \mathrm{~m})\end{array}$ & $\begin{array}{l}26 \text { Oct } \\
31 \text { Oct }\end{array}$ & $\begin{array}{l}30 \mathrm{~km} \\
30 \mathrm{~km}\end{array}$ & $\begin{array}{l}\text { 103: } 06 \\
\text { 102: } 22\end{array}$ \\
\hline Sea level & 25 Sept & $10 \mathrm{~km}$ & 29: 07.8 \\
\hline $\begin{array}{l}\text { Mexico City } \\
(2,250 \mathrm{~m})\end{array}$ & $\begin{array}{l}23 \text { Oct } \\
26 \text { Oct }\end{array}$ & $\begin{array}{l}3 \text { miles } \\
(2 \text { min rest }) \\
3 \text { miles } \\
36 \mathrm{~km}\end{array}$ & $\begin{array}{r}\text { 14: } 48 \\
\text { 14: } 46 \\
\text { 129: } 57\end{array}$ \\
\hline
\end{tabular}

it is perfectly possible to repeat a session such as $15 x$ 440 yards in 65 seconds with 55 seconds recovery jog at altitude and suffer no greater stress (allowing for a greater respiratory effort intially) than at sea level. Such a session at sea level would correlate with a $5000 \mathrm{~m}$ time of 14 minutes but, at altitude, the correlation was with a $\mathbb{D}$ time of 15 minutes. The instinct of middle-distance runners, who are rather time conscious, on discovering $\overrightarrow{\bar{B}}$ this changed relationship between training and racingperformances is not to adapt their training methods but $\frac{C}{0}$ to attempt to speed up the intervals in order to get back $\bar{\omega}$ to 14 minutes as quickly as possible. This seems to be of $\widehat{\Phi}$ significance for altitude training.

TFKJ and DMT found no obvious correlation $\bar{\square}$ between training and racing performances over training distances shorter than $1 \mathrm{~km}$. Once times could be cut ${ }_{\mathcal{O}}$ over the $1 \mathrm{~km}$ distance in training, a similar kind of $\partial$ increase in racing pace could be achieved. But, as TFKJ pointed out in a letter from Mexico City to the Road $\infty$ Runners Club in 1968, an improvement in training over-this distance only occurred for him in the fifth week at $\mathrm{N}$ altitude when his time for each interval improved by five $O$ seconds in a series of $8 \times 1 \mathrm{~km}$. At the same time, in fartlek sessions he found that whereas in the first month $\rightarrow$ it had been terribly hard to go on doing fast bursts after more than $\mathbf{4 0}$ minutes, he could manage twice that $\vec{\oplus}$ length of time after five weeks. In the early weeks one cannot help getting very worried by the terribly weak, almost helpless feeling that comes on quickly if one tries to train normally hard. In a run of any length one would generally have to stop and take an occasional walk, while even the slightest hill required a tremendous effort. This feeling should disappear about the fifth week. After the fifth week TFKJ was able to train as hard as at home. He $\overrightarrow{\overrightarrow{0}}$ still found he had to breathe much harder and faster, but 3 this is something one just has to accept. We noticed the same thing even with the Mexican runners.

Clearly there are dangers in too much training at slower than racing pace. Balke et al (1967), pointed out that the necessary reduction in pace during training as well as during competition, may affect an athlete's peak 8 performance by producing. local muscular detraining $₹$ despite the greater general strain of training at altitude. $ᄋ$

\begin{tabular}{|c|c|c|c|c|c|}
\hline \multirow[b]{2}{*}{ Place and year } & \multicolumn{4}{|c|}{$\begin{array}{l}\text { TABLE V } \\
\text { by an international athlete (DMT) } \\
\text { l and altitude, 1965-68 }\end{array}$} & \\
\hline & $\begin{array}{l}\text { Week prior } \\
\text { to altitude }\end{array}$ & \multicolumn{4}{|c|}{ Weeks at altitude } \\
\hline & & & 2 & 3 & 4 \\
\hline $\begin{array}{l}\text { Mexico City }(2,250 \mathrm{~m}) 1965 \\
\text { Font Romeu }(1,800 \mathrm{~m}) 1967 \\
\text { Mexico City }(2,250 \mathrm{~m}) 1967 \\
\text { Mexico City }(2,250 \mathrm{~m}) 1968\end{array}$ & $\begin{array}{l}80 \\
63 \\
77 \\
87\end{array}$ & $\begin{array}{r}45 \\
54 \\
63 \\
102\end{array}$ & $\begin{array}{r}58 \\
58 \\
91 \\
124\end{array}$ & $\begin{array}{r}54 \\
54 \\
105\end{array}$ & $\begin{array}{l}67 \\
91\end{array}$ \\
\hline
\end{tabular}


The power output of the muscles trained for maximum effort is definitely diminished because of the reduced oxygen supply (Balke et al, 1967, p. 185). The solution offered by Balke et al is alternate training between higher and lower elevations, and to have frequent recourse to time trials, so that the athlete never loses the skill of running his chosen distance at sea-level pace. They found that alternating training between lower and higher elevations did not interfere with the progress of adaptation to altitude.

Type of training to be undertaken at altitude on a first or only visit

Since physiological changes occur most rapidly in the first few days at altitude and since this is the period when the effort of working against an apparent resistance is most noticeable it seems logical first, to avoid undue fatigue and give the physiological mechanism a chance to adapt and second, to utilize the apparently wasted training days by going to a much higher elevation, so learning to tolerate a feeling of greater discomfort.

In their later visits to altitude, TFKJ and DMT did most of their extensive exercise (one and a half to three hours running and walking) in the first four days at altitude, at heights greater than $10,000 \mathrm{ft}(3,050 \mathrm{~m})$. They then felt better able to tolerate intensive running at a lower elevation. It is astonishing how one's attitude to running at $7,500 \mathrm{ft}(2,290 \mathrm{~m})$ changes after a day spent jogging and walking at $13,000 \mathrm{ft}(3,960 \mathrm{~m})$. In DMT's training diary for November 23, 1965 there is a note "climbed from 13,000 to 15,500 feet on Popacatepetl. Ran most of the way down and then steadily downhill on road for forty minutes."

But the main benefit of altitude training must lie in the opportunity for increasing maximum aerobic capacity, and the percentage of the athlete's maximum that he can sustain for long periods after return to sea level. Clearly the aerobic mechanism is under stress at lower running speeds at altitude, but the distance runner's instinct is to attempt to run at his familiar sea-level pace at altitude. Clearly the effect on the aerobic capacity ought to be greater and an improvement ought to be achieved on return to sea level. This is the point at which opinions differ. One view is that the athlete should attempt to reproduce at altitude the training performances of sea level, in other words that what makes sense at sea level is equally sound logic at altitude. The other view is that almost any kind of continuous running at normal sea level training cruising speeds puts a slightly increased stress on the aerobic mechanism and hence is beneficial. Until all the benefit has been gained from this form of training - and this may take five or six weeks - specific interval training is unlikely to be of much value. (We are still referring to people making a first, and possibly sole, visit to altitude.)

\section{Conclusions}

Following the logic of this latter point of view - which happens to be our own - it seems that the main benefits of altitude training will occur in the immediate preseason period, say in April and May when the competitive season starts in June. It is at this time that track athletes are trying to gain some advantage from increased strength achieved by extensive over-distance work during the winter, and to get their oxygen transport system working efficiently. Extensive running at altitude, particularly in hilly country, is ideal for this.

Using altitude training to achieve what we reckon to be a final $1 \%$ improvement in performance immediately before competition is a more difficult task, as empirical evidence suggests. Athletes are not animals, nor for that matter are they all policemen. It might well be that a $1 \%$ improvement in performance could be achieved even for an athlete in world record breaking form by methods other than that of sending him to altitude for a month immediately before his race. A cost-benefit study is called for.

For any kind of certain improvement to ensue from altitude training, a programme of regular visits at reasonably frequent intervals is required. And more research is needed on the best forms of training to be pursued by athletes training for different middle- and. long-distance events.

\section{REFERENCES}

Balke, B., Daniels, J. T., and Faulkner, J. A. (1967). "Training for maximum performance at altitude." In Exercise at Altitude. Ed. Margaria, R. Amsterdam; Excepta Medica.

Johnston, T. F. K. and Turner, D. M. (1967). Altitude Research Projects. International Athletes Club. (Mimeo).

Mellerowicz, H. et al (1970). "Comparative investigations of the effects of training at high altitudes upon endurance performance at sea level." Sportarzt Sportmed., 21, 207-215.

Pugh, L. G. C. E. (1967). “Athletes at altitude." J.Physiol., 192, 619-646. 